\title{
Uncuttable Bond: Willie's Changing Perception of His Father and His Identity
}

\author{
Jingyin Xu \\ Faculty of English Language and Culture, Guangdong University of Foreign Studies, Guangzhou 510420, Guangdong, China \\ Email: jingyinxu@163.com
}

\begin{abstract}
V. S. Naipaul, a Nobel Prize winner, portrays Willie Somerset Chandran, his protagonist in Half a Life, as a man who escapes from his homeland and searches his identity across three continents for half a life. Inversely, in the end of the story, Willie values his Indian passport and his family tie, which leads me to probe into his sharp transformed attitude. Borrowing from Stuart Hall the idea that the process of identification is "not the so-called return to roots but a coming-toterms-with our "routes", this study argues that Willie's change from trying to get rid of his original identity, even by making up a new identity, to accepting his Indian identity, is not simply a process of returning to his Indian root but a compromise with his journey, which is interweaved with his changing attitude to his father. What this study develops from Hall's opinion is that though one's identification is shaped by "route", his or her action may not follow cognition for various reasons.
\end{abstract}

Keywords: Half a Life, cultural identity, family, education, diaspora, ethnic literature

\section{Introduction}

Cultural identity is hotly debated in the context of globalization since the dwellers have more changes to cross cultural boundaries in multiple ways. In such a context, V. S. Naipaul, portrays Willie Somerset Chandran, his protagonist in Half a Life, as a man who searches his identity across three continents for half a life. Ironically, Willie spends half a life escaping from his Indian identity, only to find that he thinks highly of his Indian identity and family tie nearly in the end of the story. The elements which trigger the transformation of Willie's cognition of his identity are therefore worth of discussion, which does not appear so far to have attracted notice. Many recent studies have explored Willie's identity construction. For example, Fazel Asadi Amjad and Ghamereddin Badirdast (2016) argue that Willie is trained to be an orientalist under the colonial education. The education Willie receives in mission school as well as in college in London do shape Willie's perception of his identity, but these two scholars seem to miss the more important element — the force of his family. Willie longs for leaving his home because of his negative feelings for his father, but he is disappointed for what he experiences in London. Thus, the family factor calls for further discussion. Though previous studies like Li Xue's analysis (2004) explain how the father and the son searching for their root, they do not discuss how Willie's varying attitude to his father reshapes his cognition of his identity. This thesis argues that Willie Chandran's transformation from escaping his original identity, even by making up a new identity, to accepting his Indian identity, is not just a process of returning to his "root" but a compromise with his "route", and this is interweaved with his changing attitude to his father. It is worth adding that though Willie's cognition compromises with his "route" or journey, his action does not follow his perception, which will be further explained. Through studying the text, this thesis aims to reveal how family factors and traveling experience influence one's identity construction.

To "re-make himself" is Willie's attempt to express his hatred of his father. Thus, in the following discussion, this thesis will firstly examine how and why Willie pretends as a Canadian when he is in mission school and "re-make himself" by playing words after he arrives in London. Next, this thesis will discuss how Willie's experience reshapes his cognition of his father and his identity. The last part of analysis will illustrate the contradiction between the importance of Indian passport for Willie and his choice of visiting his sister in Germany instead of returning to India even though he has reconciled with his father in mind.

\section{Willie's attempt to "re-make" himself}

Willie's attempt to "re-make himself" is actually a kind of resistance to his father. After hearing his father's story, Willie, in his young little heart, disdains his father and longs for breaking away from his original identity as an Indian. The story of Half a Life starts with Willie Chandran's question of why his middle name is "Somerset" and his father tells 
a story, in which the father pictures his "life of sacrifice", and such a "satirical representation of personal weaknesses and social limitations" (Nie 113) is one of the important themes running through Naipaul's works. Take the marriage of Willie's parent as example. Willie's father believes that "to marry the lowest person I could find" (Naipaul 12) is the way to fight for equality as Gandhi promotes, which can be better understood if we put it into the background of pre-liberated India. Willie's father calls what he does as "sacrifice", which, for him, a great deed. However, deep in his mind, Willie's father looks down upon the girl he marries, as he puts it, "that pregnancy, that distending of her stomach, that alteration of her already unattractive body, tormented me, made me pray that what I was witnessing wasn't there" (Naipaul 33). Willie's father marries the girl because of the pregnancy, but he does not love her. For him, the girl is just a tool and an excuse for him to turn his back to his ancestor and his father. Willie certainly condemns his father for his behavior and his ignorance of Willie himself, as he says "I despise you" in the end of chapter one. Because of his hatred, he yearns for going abroad and adapting his identity.

His identification, however, is changing together with his attitude to his father, as Stuart Hall puts it, "identification as a construction, is a process never completed-always "in process"” (3). Willie's understanding of his identity changes along with his feelings for his father. In the beginning of the story, the conflict between the father and the son is intensive. Family relationship is essential for a child to build up his or her identity, but Willie's father as well as his ignorant mother push him far away. As he grows up, he understands more about the mission school, and he begins "to look at his mother from more and more of a distance" (Naipaul 38), which drives him to embrace the Western world. He desires to go to Canada, the country his teachers come from, and he even thinks "he might adopt their religion and become like them and travel the world teaching" (Naipaul 38). Then he put his yearnings into practice - to write as a Canadian in an English composition assignment, which is awarded "full marks, ten out of ten, and Willie was asked to read it out to the class" (Naipaul 39). The highly admiration of his teacher, classmates and even his mother strengthens his desire to change his identity. Willie wants to change his identity not because he is shamed to be an Indian but because the conflict between the father and the son. When his father pushes him out, the western world is waving to him, which reshapes his identification, as Madan Sarup states, "all identities, whether based on class, ethnicity, religion or nation, are social constructions" (48). The highly approval for Willie's composition is actually a kind of confirmation of his writing capability and his inclination of identification. The education in mission school thus plays an important role in constructing Willie's identity.

\section{The likeness between the father and the son}

Willie's dual identities as a "London man" and an Indian lead him to realize that he shares likeness with his father and to understand his father, which continually influences his cognition of his identity. Though Willie does not go to Canada as he wishes at the very beginning, he is sent to London to study, and "he wishes, in London, to steer clear of his father, and to get by on his own" (Naipaul 53), but the story does not go as he wishes. On the contrary, what he counters in London reshapes his understanding of his father as well as his identity. He feels unsettled and confused about London, the city in which the new immigrants are still not widely accepted after the World War Two. In addition, no one he meets knows "the rules of Willie's own place", which allows him to "present himself as he wished" (Naipaul 57). Though social elements such as education, discourse and language play an important role in constructing his cultural identity, Willie Chandran's attempt to get rid of his original identity by making up an identity in London has an important but often neglected function in exploring his identity. The education he accepts at the mission school continued to influence him, as the following passage suggests:

He adapted certain things he had read, and he spoke of his mother as belonging to an ancient Christian community

of the subcontinent, a community almost as old as Christianity itself. He kept his father as a Brahmin. He made his

father's father a "courtier". (Naipaul 59)

By playing with words, Willie "began to re-make himself" (Naipaul 59). The attempt to make up a new identity also "began to give him a feeling of power" (Naipaul 58). Here Willie begins to blend in with his surroundings. Similarly, his action of creating a new identity wins the teacher's acknowledge again, as his teacher says to him, "You seem to be settling in" (Naipaul 58). Willie also encounters English imagination about his Indian life, "The journalist asked about the babu; Willie didn’t correct him" (Naipaul 54). Willie's psychological activity, at this moment, is complex. On the one hand, he is ashamed for his father, "who must have been mocked by the journalist in what he wrote" (Naipaul 55); on the other hand, he is depressed for "having gone back on his decision to stay away from his father's friends" (Naipaul 55). He chooses to cater to English imagination of Indians as his father does since it is dangerous to challenge Westerners" imagination. It is after this experience that Willie receives a letter from "the great writer after whom Willie was named" (Naipaul 55), and because of the experience, Willie begins to understand his father, as he narrates: 
I misjudged my father. I used to think that the world was easy for him as a brahmin and that he became a fraud out of idleness. Now I begin to understand how hard the world must have been for him. (Naipaul 55)

Furthermore, Willie's incompetence in sex forces his to think of "his father with compassion for the first time" (Naipaul 66). Willie is actually showing his similarity with his father to readers, but it is not until Willie's sister Sarojini points out the commonality they share that Willie realizes he is like his "poor father", as he asserts, "when my father told me his life story and talked about his sexual incompetence, I mocked him. I was a child then. Now I discover I am like my poor father" (Naipaul 110).

\section{The land Willie chooses not to return}

Willie leaves India, in the first place, for his hatred of his father, but his experiences have reshaped his attitude to his father. Because of contingency, Willie writes a book which is "artificial and false", but the book catches an African girl's attention. After their meeting, they fall in love and move to Africa together, and the experience in Africa can help us "to think about identities in terms of contingency" (Barker 88). Willie's losing passport in Africa is another example of contingency, and it is because of this contingent event that Willie displays that he cherishes his Indian passport. For him, his Indian passport is a certification of his identity, thus he asserts "Without my passport I had no credentials, no claim on anyone. I would be lost. I wouldn't be able to move" (Naipaul 148). Therefore, Willie's cognition of his identity interrelates with his changing attitude to his father, and his seeking identity, is "not the so-called return to roots but a coming-to-terms-with our 'routes"” (Hall 4). What Hall does not mention but displays in the novel is that though one's cognition compromises with one's "route" or journey, one's action may not follow his or her cognition. Though Willie emphasizes the importance of Indian passport, he chooses not to return to India not for his revulsion against his father anymore but because he knows that if he returns to India, he would be restricted by Indian culture. Returning to home, for him, means arrange marriage and battles, “I don’t like marrying someone like Sarojini, and that's what will happen if I go home. If I go home, I will have to fight the battles my mother's uncle fought. I don't want to fight those battles. It will be a waste of my precious life" (Naipaul 110). The story begins by "his father had told Willie about his life", and ends by Willie tells Sarojini of "his life in Africa" (Naipaul 131). When Willie narrates his story, he is actually talking about his identity, as Sarup believes, "our identity is not separate from what has happened" (15).

\section{Conclusion}

All of these being said, this thesis proves that Willie's perception of his identity is embedded with his changing attitude to his father, and this is a process of compromising with his "route". Besides, what we need to develop from Hall's idea is that though one's cognition of identity compromises with one's "route", his or her action may not follow cognition. Through the discussion all above, this thesis also tries to reveal the possible influences of family factors and traveling experience on one's identity construction.

\section{References}

[1] Amjad, Fazel Asadi, et al. Ontological and Epistemological" Discourse of Cultural Indentity: Making an Orientalist in V.S. Naipaul's Half a Life. Theory and Practice in Language Studies. 2016; 6(6): 1200-1206.

[2] Chen, Yongguo. Identification and the Politics of Literature. Journal of Tsinghua University (Philosophy and Socia Sciences). 2016; 31(6): 22-31.

[3] Barker, Chris. Cultural Studies: Theory and Practice. London: Sage Publications Ltd; 2000.

[4] Hall, Stuart. Question of Cultural Identity. London: Sage Publications Ltd; 2011.

[5] Li, Xue. Father and Son's Searching for a House in Limbo: An Interpretation of Half a Life by V .S. Naipaul. The Northern Forum. 2004; (3): 48-50.

[6] Naipaul, V.S. Half a Life. New York: Random House; 2001.

[7] Nie, Wei. The Art of Satire in Naipaul's Half a Life. Masterpiece Appreciation. 2007; 113-116.

[8] Sarup, Madan. Identity, Culture and the Postmodern World. Edinburgh: Edinburgh University Press; 1998. 